\title{
Factors Affecting the Indonesia Stock Exchange: A Multi-Index Approach
}

\author{
Didik Susilo $^{1}$, Sugeng Wahyudi ${ }^{2} \&$ Irene Rini Demi Pangestuti $^{2}$ \\ ${ }^{1}$ Doctoral Program in Economics, Universitas Diponegoro, Semarang, Indonesia \\ ${ }^{2}$ Faculty of Economics and Business, Universitas Diponegoro, Semarang, Indonesia \\ Correspondence: Didik Susilo, Faculty of Economics and Business, Universitas Diponegoro, Semarang, Indonesia. \\ Tel: 62-8151-835-227.
}

Received: November 27, 2019

Accepted: December 23, 2019

Online Published: March 17, 2020

doi:10.5430/ijfr.v11n2p196

URL: https://doi.org/10.5430/ijfr.v11n2p196

\begin{abstract}
This study examines the influence of world and regional capital market conditions on the Indonesian capital market (Indonesia Stock Exchange) condition. The DJIA (Dow Jones Industrial Average) index was used as a representative of the international capital market while the Hang Seng index and the Nikkei 225 index were used as a representative of regional capital market conditions. These two indices were chosen because the Japanese capital market was one of the most advanced capital markets in the world and the Hong Kong capital market, although not as big as Japan, still played an important role in the world. The data were obtained from Yahoo Finance during the period of 2014-2018. The dependent variable was the change in the JCI (Jakarta Composite Index), while the independent variables were changes in the index of DJIA, Nikkei 225 and Hang Seng index. Using daily data analyzed by the ARIMA method $(1,1)$, it was found that there was a significant positive effect of DJIA with lag 1 and Hang Seng index on the JCI, but no significant effect was found from the Nikkei 225 index on the JCI.
\end{abstract}

Keywords: capital market integration, multi-index model, Indonesia Stock Exchange, Dow Jones Industrial Average (DJIA), Nikkei 225, Hang Seng and ARIMA

\section{Introduction}

\subsection{Background of the Study}

In the era of globalization where economic boundaries between countries have increasingly blurred, economic activity is not only limited to the domestic environment but has been cross country. The current globalization also has quite broad implications on the flow of funding and investment as well as macroeconomic development (Muharam, Mawardi, Arfinto, \& Najmudin, 2019; Robiyanto, 2018). Capital market liberalization and rapid developments in the telecommunications sector have significantly increased the ability to disseminate information between capital markets. As a result, the capital market is becoming increasingly integrated (Chkioua, 2013).

Sharma and Seth (2012) stated that the capital market was considered internationally integrated if assets with the same (identical) risk would have the same price even if traded on different capital markets. This means that risks and returns apply internationally and the movement of shares in the capital market is not only influenced by domestic factors but also by the price of securities in the world capital markets. Currently, there is a lot of evidence that the world capital markets, in general, are becoming more integrated. In a case where a country's capital market is integrated with the world capital market, Sharma and Seth (2012) suggested that there was an information relationship between the local capital market represented by a composite stock price index in a country with the world capital market such as the Dow Jones Industrial Average (DJIA) index. They even detected a reciprocal relationship between the two. Meanwhile, Robiyanto and Ernayani (2018) showed that there was an interdependence between local and world capital markets as measured using the DJIA index indicator. Antoniou, Pescetto, and Stevens (2007) found that the condition of the American capital market was such a global factor that affected both the established and the emerging market.

Many researchers suggest that the integration of international capital markets is currently growing and can improve efficiency in the global capital market. Seth and Sharma (2015) examined the 13 capital markets in Asia and the US, they found that those capital markets had a homogeneous nature. The capital market conditions in these countries are represented by the combined stock price indexes of each country, for example the condition of the Hong Kong Stock 
Exchange is represented by the Hang Seng index, the Singapore Stock Exchange is represented by the Strait Times Index, the Tokyo Stock Exchange is represented by the Nikkei 225 index. In a different research, Kim and McKenzie (2008) explicitly stated that shocks to the United States stock market greatly affected the capital markets in the Asian region, further emphasizing that the stock price indexes of countries in the Asian region were strongly affected by these conditions.

Considering the conditions above, the benchmarks used in the context of asset pricing are no longer local stock price indices but must refer to the world stock price index (Najmudin, Syarif, Wahyudi, \& Muharam, 2017). For example, risk should be measured using the world stock price index compared to the local stock price index. Sharpe, Gordon, and Bailey (1995) stated that if observations were made, it would appear that when the market improved (as indicated by the available stock price index), the prices of individual shares would also increase and vice versa where when the market went bad, the price of shares would fall. This shows that the profit level of stock seems to be correlated with the market changes. The model is commonly known as the single-index model.

However, looking at developments that actually are not only based on one factor affecting the stock market conditions, a multi-index model then developed (Soufian, 2001). In the model, there are various factors expected to influence the stock market conditions (McKenzie, Brooks, \& Faff, 2000; Wahyudi, Hersugondo, Laksana, \& Rudy, 2017; Yunita \& Robiyanto, 2018). For example, the use of international stock price index such as the DJIA, and regional capital market indices such as the Nikkei 225 and Hang Seng index. Although there are many indicators of share price movements for countries in the Asian region that can be used as benchmarks for regional stock movements, most of the existing capital markets are still categorized as emerging markets rather than established markets, which could be used as regional benchmarks.

Liu, Pan, and Shieh (1998) stated that only two capital markets in the Asian region were included in the developed capital market category. They were the Tokyo Stock Exchange with the Nikkei 225 index as an indicator and the Hong Kong Stock Exchange with the Hang Seng index as an indicator. The Japanese capital market is a highly developed capital market and one of the largest in the world while the Hong Kong capital market, although not as large as the Japanese capital market, plays an important role in international investment activities. The Hong Kong capital market has a market capitalization of $2 \%$ of all developed capital market capitalization in the world (Huang, Yang, \& $\mathrm{Hu}$, 2000).

Soufian (2001) stated that most researches were more focused on the use of a single index model and only a few studies used the multi-index model. Therefore, in this study, the multi-index model will be used to address the existing problems. This study seeks to examine the effect of the world/global stock price index (in this case is the Dow Jones Industrial Average Index / DJIA) and regional stock indexes such as the Nikkei 225 and Hang Seng index on the market conditions in the Indonesia Stock Exchange. The S\&P index was not used in this study because the index could already be replaced by the DJIA.

The existence of relationships in the stock exchanges in the world causes a stock not only influenced by the condition of the country's capital market, but also by the condition of the world capital market. Current studies suggest that exchanges in the world are interconnected with one another. However, the most influential stock market on the condition of capital markets in the world is the New York Stock Exchange with the DJIA as the indicator. The DJIA index is also a benchmark for the world markets. It is interesting to investigate its influence on the stock exchange in Indonesia (represented by the Indonesia Stock Exchange), considering that so far the focus of existing research has tended to be only in the use of local capital market indices. It should also be noted that besides the DJIA index, regional stock indices such as the Nikkei 225 and Hang Seng index are also expected to have an influence on the condition of the Indonesia Stock Exchange.

\subsection{Literature Review}

\subsubsection{Capital Market Integration}

According to Sharma and Seth (2012), capital markets are considered internationally integrated if assets with the same (identical) risk will have the same price even if traded on different capital markets. Lately, there have been indications of an acceleration of the integration process among the capital markets in the world. This may occur because of the gradual exemption of restrictions on share ownership by foreign parties imposed by a government in some capital markets. Rapid developments in information and communication technology also support this process.

An increasingly integrated capital market makes it easy for international investors to diversify internationally. However, the more integrated the capital markets, the higher the correlation of capital markets of one country with other countries (Muharam et al., 2019; Oprea \& Stoica, 2018; Seth \& Sharma, 2015). Several existing types of research 
mostly examine the relationship of capital markets in developed countries. There is still little research that focuses on capital markets in developing countries, especially in countries in Asia.

\subsubsection{Multi-Index Model}

One of the most influential model in finance is the single index model. Sharpe (1964) developed a model commonly called as the single index model to simplify the calculation of stock returns. Its main characteristic is that this model assumes that there is only one factor that influences the return of securities. The methodology most frequently used in estimating market beta is to do time series regression, and then perform cross-sectional regression between the average profit rate and beta estimated from the time series regression (Robiyanto, Santoso, \& Ernayani, 2019). Lintner (1965) used the same method employed by Sharpe (1964) plus the use of unsystematic risk variables (represented by the variance of residual terms) and found that the value of the intercept was too high and the residual terms were included in the pricing. Most of these studies still use the single index model method. Jobson and Korkie (1981) stated that the multi-index model had a better coefficient of determination compared to the single-index model. This also supported by Donaldson and Ingram (2014); Xia (2012).

Diaz and Pandey (2019) applied multi regression to further investigate the relationship between the returns of hi-tech and financial industry stocks in selected markets and industry variables. The assumption underlying this model is that there are other variables outside the variables used in the single index model that affect a stock. The model proposed will depend on the type of explanatory variable chosen. Differences in explanatory variables will cause the results of the research to be different. Thus, the superiority or inferiority of multiple index models will be greatly influenced by the type of explanatory variables that exist in the model. While, Yunita and Robiyanto (2018) using the inflation rate, exchange rate and inflation to determine the stock prices index.

\section{Method}

The data needed in this study are as follows:

1. JCI daily closing during the study period (January 2014 to December 2018).

2. The Dow Jones Industrial Average (DJIA), Nikkei 225 and Hang Seng index daily close during the study period (January 2014 to December 2018).

All data was obtained from Yahoo Finance. The classical assumption test was done so that the results of the regression analysis met the criteria of BLUE (Best, Linear, Unlock Estimator). This classical assumption test consisted of normality, multicollinearity, autocorrelation, and heteroscedasticity test. If there was a deviation in the classical assumption test, the regression equation model formed would be revised by adjusting the data conditions. The regression equation model used in this study was the Box-Jenkins model or commonly referred to as the ARIMA (Autoregression Integrated Moving Average). This method could accommodate the data conditions that were not normally distributed and suitable for time series data. The ARIMA / Box-Jenkins method differed from other methods that did not assume a pattern in the time series historical data. The model would be suitable if the residuals were small, randomly distributed (white noise) and not bound to one another. To avoid violating the classical regression assumptions where the data used for regression analysis must be normal, the ARIMA method was considered in accordance with the possibility of finding the data that was not normally distributed because the stock market returns were a free and bound variable. Kamath, Chakornpipat, and Chatrath (1998); Ogata (2012) stated that stock market returns tended not to be normally distributed.

The ARIMA model $(1,1)$ used as an alternative in this study is as follows:

\section{Model I}

$$
\Delta \mathrm{JCI}==\alpha+\beta 1 \Delta \mathrm{JCI}_{\mathrm{t}-1}+\beta 2 \Delta \mathrm{DJIA}+\beta 3 \Delta \text { NIKKEI } 225+\beta 4 \Delta \text { HANG SENG }+\mathrm{e}_{\mathrm{t}}+\mathrm{W}_{\mathrm{t}} \mathrm{e}_{\mathrm{t}-1}
$$

Where:

$\begin{array}{lll}\triangle \mathrm{JCI} & : & \text { Level of change in JCI } \\ \triangle \mathrm{DJIA} & : & \text { Level of change in the DJIA Index } \\ \triangle \mathrm{NIKKEI} \mathrm{225} & : & \text { Level of change in the Nikkei 225 Index } \\ \Delta \mathrm{HANG} \text { SENG } & : & \text { Level of change in the Hang Seng Index } \\ \alpha & : & \text { Constant } \\ \beta 1, \beta 2, \beta 3, \beta 4 & : & \text { Regression Coefficient } \\ \Delta \mathrm{JCI}_{\mathrm{t}-1} & : & \text { Lag variable }\end{array}$




$\begin{array}{ll}\mathrm{W}_{\mathrm{t}} & : \text { Weight } \\ \mathrm{e}_{\mathrm{t}} & : \text { Residual error } \\ \mathrm{e}_{\mathrm{t}-1} & : \text { Lag Residual error }\end{array}$

Model II

$$
\Delta \mathrm{JCI}=\alpha+\beta 1 \Delta \mathrm{JCI}_{\mathrm{t}-1}+\beta 2 \Delta \mathrm{DJIA}_{\mathrm{t}-1}+\beta 3 \Delta \text { NIKKEI } 225_{\mathrm{t}-1}+\beta 4 \Delta \text { HANG SENG }_{\mathrm{t}-1}+\mathrm{e}_{\mathrm{t}}+\mathrm{W}_{\mathrm{t}} \mathrm{e}_{\mathrm{t}-1}
$$

Where:

\begin{tabular}{|c|c|c|}
\hline$\Delta \mathrm{JCI}$ & : & Level of change in JCI \\
\hline$\Delta$ DJIA $_{t-1}$ & : & Lag variable of level of change in the DJIA Index \\
\hline$\Delta$ NIKKEI $225_{t-1}$ & & Lag variable of level of change in the Nikkei 225 Index \\
\hline$\Delta \mathrm{HANG}_{\mathrm{SENG}} \mathrm{t}-1_{1}$ & : & Lag variable of level of change in the Hang Seng Index \\
\hline$\alpha$ & : & Constant \\
\hline$\beta 1, \beta 2, \beta 3, \beta 4$ & : & Regression Coefficient \\
\hline$\Delta \mathrm{JCI}_{\mathrm{t}-1}$ & 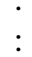 & Lag variable of level of change in JCI \\
\hline W & : & Weight \\
\hline e & ? & Residual error \\
\hline$e_{t-1}$ & : & Lag Residual error \\
\hline
\end{tabular}

Model III

$$
\Delta \mathrm{JCI}=\alpha+\beta 1 \Delta \mathrm{JCI}_{\mathrm{t}-1}+\beta 2 \Delta \mathrm{DJIA}_{\mathrm{t}-1}+\beta 3 \Delta \text { NIKKEI } 225+\beta 4 \Delta \text { HANG SENG }+\mathrm{e}_{\mathrm{t}}+\mathrm{W}_{\mathrm{t}} \mathrm{e}_{\mathrm{t}-1}
$$

Where:

$\begin{array}{lll}\Delta \mathrm{JCI} & : \text { Level of change in JCI } \\ \Delta \mathrm{DJIA}_{\mathrm{t}-1} & : & \text { Lag variable of level of change in the DJIA Index } \\ \Delta \mathrm{NIKKEI} 25 & : & \text { Level of change in the Nikkei } 225 \text { Index } \\ \Delta \mathrm{HANG} \text { SENG } & : & \text { Level of change in the Hang Seng Index } \\ \alpha & : & \text { Constant } \\ \beta 1, \beta 2, \beta 3, \beta 4 & : & \text { Regression Coefficient } \\ \Delta \mathrm{JCI}_{\mathrm{t}-1} & : & \text { Lag variable of level of change in JCI } \\ \mathrm{W} & : \text { Weight } \\ \mathrm{e} & : \text { Residual error } \\ \mathrm{e}_{\mathrm{t}-1} & & \text { Lag Residual error }\end{array}$

The ARIMA model testing would be carried out using the log likelihood value.

\section{Results and Discussions}

\subsection{Data Specification}

Data specification was performed to determine the condition of existing data to determine the most appropriate analysis model to use. The data in this study was tested first with a series of tests consisting of the one-way Kolmogorov-Smirnov test to test statistical normality, autocorrelation tests using Durbin Watson statistics and data stationarity test, multicollinearity test by looking at Variance Inflation Factor (VIF) and heteroscedasticity tests using Durbin-Watson statistics and data stationarity test, multicollinearity test by looking at the Variance Inflation Factor (VIF) and heteroscedasticity test using Box-Ljung Q statistics.

\subsubsection{Normality Test}

A normality test was performed to determine whether data was normally distributed statistically or not. It was done using the one-way Kolmogorov-Smirnov model. The following Table 1. presents the result of normality test. 
Table 1. Result of the normality test

\begin{tabular}{lll}
\hline Index & Kolmogorov-Smirnov Z & Asymptotic Significance \\
\hline JCI & 2.754 & 0.000 \\
DJIA & 0.794 & 0.501 \\
HANGSENG & 0.001 & 0.999 \\
NIKKEI225 & 1.038 & 0.204 \\
\hline
\end{tabular}

Source: Yahoo Finance, processed

From the table above, it could be concluded that the JCI return data were not normally distributed. This could be seen in the highly significant value of Kolmogorov-Smirnov Z. Meanwhile, the DJIA, Hangseng and Nikkei225 return is normally distributed. Due to the not-normally distributed data of the JCI which initially would be used as the dependent variable, a multiple regression analysis could not be carried out to avoid violating the classical regression assumptions.

\subsubsection{Autocorrelation Test}

The Durbin-Watson statistical value in this study is 1.954 which is still in the range of criteria for no autocorrelation. For this reason, it could be concluded that there was no autocorrelation on the dependent variable that would be used.

\subsubsection{Multicollinearity Test}

A method that could be used to test multicollinearity was by looking at tolerance value or Variance Inflation Factors (VIF). The tolerance value limit is 0.10 and the Variance Inflation Factors (VIF) are 10 (Hair, Black, Babin, \& Anderson, 2009). If the tolerance value is below 0.10 or the Variance Inflation Factors (VIF) value is above 10, then multicollinearity occurs. The other way was by seeing the condition index. The theoretical value of the condition index is 20 if it is greater than the value, it is indicated that there is multicollinearity.

Table 2. Result of multicollinearity test

\begin{tabular}{lll}
\hline Variable & Tolerance & VIF \\
\hline DJIA & 0.903 & 1.107 \\
HANG SENG & 0.818 & 1.222 \\
NIKKEI & 0.581 & 1.721
\end{tabular}

Condition Index: 1.899

Source: Yahoo Finance, processed

From Table 2, it can be seen that the tolerance value of all variables is above 0.10 and the value of Variance Inflation Factors (VIF) is below 10 and the condition index coefficient is under 20.

\subsubsection{Heteroscedasticity and Stationary Test}

Seiler and Rom (1997) used the Box-Ljung test with 16 lag periods to test the stationarity of data with $\alpha=5 \%$. If there was only a maximum of 2 significant lag periods in the 16 lag periods, then the data was considered stationary. If there were more than 2 significant lag periods, then the data was considered not stationary. The stationarity of the data could also be seen in the ACF (Autocorrelation Function) value. If the ACF was greater than the confidence limit (seen on the correlogram), then the data was not stationary. The results were not much different from when using the Statistical Box-Ljung. Below, Table 3 presents the result of the heteroscedasticity test. 
Table 3. Result of heteroscedasticity test

\begin{tabular}{lllll}
\hline Index & Box-Ljung & Statistics (16) & $\begin{array}{l}\text { Number of Box-Ljung } \\
\text { Significant at 16 Lag }\end{array}$ & Statistics \\
\hline JCI & Q-Statistics (16) & Prob. & & \\
DJIA & 16.101 & 0.433 & 1 & \\
HANGSENG & 11.419 & 0.770 & 0 & \\
NIKKEI & 12.643 & 0.701 & 0 & \\
\hline
\end{tabular}

Source: Yahoo Finance, processed

From Table 3 above, it could be concluded that all data used including the JCI, DJIA, Hangseng and Nikkei 225 return were stationary because the number of statistically significant Box-Ljung is not more than 2 . There is no statistically significant $Q$ at $\alpha=5 \%$ which shows no heteroscedasticity in each of these data.

3.2 Analysis of the Effect of International and Regional Capital Market Conditions on the Indonesia Stock Exchange Condition

Based on the normality test, the Durbin-Watson test, and the Box-Ljung test, it is found that the data are not normally distributed, but there is no autocorrelation, heteroscedasticity and multicollinearity problem. As the existing data are not normally distributed, if a multiple regression analysis is carried out, it will violate the classical regression assumptions and multiple regression analysis cannot be carried out. Thus, the more appropriate method should be used and it should be in accordance with the conditions of the existing data. Therefore, according to the characteristics inherent in the data, the ARIMA (Autoregression Integrated Moving Average) method was feasible to use because the data met the requirements.

Table 4. Result of ARIMA analysis

\begin{tabular}{lllll}
\hline No. & Variable & Model 1 & Model 2 & Model 3 \\
\hline 1. & Constanta & 0.001 & 0.001 & 0.001 \\
& & $(0.892)$ & $(1.101)$ & $(0.718)$ \\
2. & DJIA & 0.078 & & \\
& & $(0.516)$ & & 0.457 \\
3. & Hangseng & 0.487 & & $(5.401)^{* * *}$ \\
& & $(5.994)^{* * *}$ & & -0.074 \\
4. & Nikkei & -0.060 & & $(-0.663)$ \\
& & $(-0.580)$ & & 0.210 \\
5. & Lag DJIA & -0.141 & 0.311 & $(1.659)^{*}$ \\
& & $(-0.579)$ & $(2.326)^{* *}$ & \\
6. & Lag Hangseng & -0.281 & 0.041 & \\
& & $(-0.885)$ & $(0.432)$ & \\
7. & Lag Nikkei & & 0.111 & -0.238 \\
& & & $(0.988)$ & $(-0.598)$ \\
8. & AR1 & & -0.219 & -0.377 \\
& & & $(-0.565)$ & $(-1.006)$ \\
9. & MA1 & & -0.387 & $14.842^{* * *}$ \\
& & & $(-1.003)$ & 606.318 \\
\hline
\end{tabular}

Note: Numbers in parentheses are t-value: *** significant at the $1 \%$ level; ** significant at the $5 \%$ level; * significant at the $10 \%$ level

Source: Yahoo Finance, processed 
In Table 4 above, it can be seen that in Model 1 or the model that uses the current period, a significant positive effect of Hang Seng return is found. It is one of the representatives of the capital market conditions in the regional area. The regression coefficient value of this variable is 0.487 with a t-value of 5.994 significant at the $1 \%$ significance level. Meanwhile, other independent variables such as the DJIA return representing international capital market conditions and the Nikkei return which is also one of the representatives of regional capital markets in the region did not have a significant effect. The sign of the DJIA regression coefficient is positive which indicated that the movement of the DJIA with the JCI tended to go hand in hand, but this was not the case with the Nikkei which has a negative sign of the regression coefficient, indicating the opposite movement between the JCI and Nikkei. However, the coefficient was not significant.

Geographical location was expected to cause time differences in trading transactions on each stock exchange. Therefore, it was necessary to use the variable 1-period lag in the analysis. Thus, in model II, the lag variables are used from all the independent variables used in this study. In model II which uses the lag variable, it was found that the DJIA return representing changes in international capital market conditions with a 1-period lag has a significant positive effect on changes in the condition of the Indonesia Stock Exchange. The regression coefficient for the DJIA variable with 1-period lag is 0.311 with a t-value of 2.326 significant at the $5 \%$ significance level. Meanwhile, the lag variable from the Hang Seng and Nikkei does not have a significant effect. The Nikkei and Hang Seng regression coefficient signs are the same as the first model. The Hang Seng has no significant effect on this lag model because the Hong Kong Stock Exchange and Tokyo Stock Exchange trading hours were only a few hours away with the trading time on the Indonesia Stock Exchange on the same day. Thus, the effects of changes or movements were immediately experienced on the same day and not on the day after.

The combination of the use of lag and ordinary variables can be seen in model III. In this model III, there is only one independent variable used with a lag period because, in the previous model (model II), only one independent variable has a significant influence. Therefore, in this model III, a combination of lag and regular variables is used, including DJIA with 1-period lag and Hang Seng and Nikkei.

The suitability of the model with the data can be seen in the log-likelihood values of each of the models I, II and III. This log-likelihood was a substitute for adjusted R square (Greene, 2003). Based on Table 4., it could be concluded that Model III was the best model because it has the smallest log-likelihood value of 606.318 , while the less good model is Model II which has the largest log-likelihood value of 610.815 .

\subsection{Discussions}

The model used is model III. After analyzing the research results that have been described, this study finds that there was a significant positive effect of international capital market conditions represented by the DJIA index on the condition of the Indonesia Stock Exchange. However, the influence that occurred was the influence of the previous day's conditions. The time difference between the countries in this study led to the occurrence of time intervals on each trading day in the capital markets of these countries. This finding supports Chan, Chockalingam, and Lai (2000); Hargis (2000); Kot and Tam (2016).

This study finds also that there was a significant positive effect of regional capital market conditions represented by the Hang Seng index on the condition of the Indonesia Stock Exchange. In contrast to the conditions in the United States, trading time on the Hong Kong stock market had a relatively shorter time interval, whereas the opening of stock trading on the Hong Kong Stock Exchange was one hour earlier than the opening of stock trading on the Indonesia Stock Exchange. Therefore, the movement of the JCI and Hang Seng index tended to go hand in hand. This finding is consistent with Arsyad (2015); Kim and McKenzie (2008); Robiyanto (2018); Seth and Sharma (2015); Thomas, Kashiramka, and Yadav (2017).

Meanwhile, it was also found that there was no significant influence from the condition of regional capital markets represented by the Nikkei 225 index. The stock price movements on the Tokyo Stock Exchange tended to move independently and were not influenced by international factors. While the JCI movement tended to follow the movement of the international capital market. Therefore, it was not surprising that there was no significant influence from the Nikkei 225 on the JCI. This finding is consistent with Robiyanto (2018) and Arsyad (2015).

\section{Conclusion and Implication}

This study finds DJIA index and Hang Seng index have a positive and significant effect toward the JCI, while Nikkei 225 do not have any impact on the JCI. Based on this finding, Stock investors should pay attention to the international capital market conditions that can be seen through the DJIA index indicators and regional conditions that can be seen through the Hang Seng index. This applies to the investors in investing in the Indonesia Stock 
Exchange. They need to pay close attention to the closing of the DJIA index on the previous day because changes in the DJIA index can give a signal of the condition of the JCI.

Another recommendation is investors of other products in the capital market such as stock index futures that use the composite stock price index as their underlying assets need to use the condition of the international stock market represented by the DJIA as a guide to its investment direction. In addition, derivative product investors should also need to refer to the movement of the Hang Seng index, and even put more emphasis on the index. This is based on the idea that the derivative products have a fairly high level of vulnerability and tend to change within seconds. Therefore, the most actual information reflected in the movement of the Hang Seng index is seen as more adequate as a reference for investments in derivative products compared to investments in stocks. An interval of one hour in the trading opening is seen as being more powerful to provide information than an interval of a day.

Future researchers who are interested in studying the same field, it is advisable to use a longer period of time in order to obtain an overall picture during this long time. It is also recommended to study the stock price index that is not used in this study.

\section{References}

Antoniou, A., Pescetto, G. M., \& Stevens, I. (2007). Market-wide and Sectoral Integration: Evidence from the UK, USA and Europe. Managerial Finance, 33(3), 173-194. https://doi.org/10.1108/03074350710718266

Arsyad, N. (2015). Integration Between East and Southeast Asian Equity Markets. Journal of Financial Economic Policy, 17(2), 104-121. https://doi.org/10.1108/JFEP-02-2014-0012

Chan, K., Chockalingam, M., \& Lai, K. W. L. (2000). Overnight Information and Intraday Trading Behavior: Evidence from NYSE Cross-Listed Stocks and Their Local Market Information. Journal of Multinational Financial Management, 10, 495-509.

Chkioua, D. H. (2013). Time Varying International Market Integration. International Journal of Economics and Finance, 5(11), 63-71.

Diaz, J. F., \& Pandey, R. (2019). Factors Affecting Return on Assets of Us Technology and Financial Corporations. Jurnal Manajemen dan Kewirausahaan, 21(2), 134-144. https://doi.org/10.9744/jmk.21.2.134-144

Donaldson, J., \& Ingram, M. A. (2014). Applying Multi-Factor Models of Stock Returns: Student Exercises and Applications. Journal of Financial Education, 40(3/4), 1-21.

Greene, W. H. (2003). Econometric Analysis (5th ed.). New Jersey: Prentice Hall.

Hair, J. F., Black, W. C., Babin, B. J., \& Anderson, R. E. (2009). Multivariate Data Analysis (7th ed.). Pearson.

Hargis, K. (2000). International Cross-Listing and Stock Market Development in Emerging Economies. International Review of Economics \& Finance, 9, 101-122.

Huang, B.-N., Yang, C.-W., \& Hu, J. S.-S. (2000). Causality and Cointegration of Stock Markets Among The United States, Japan, and the South Chine Growth Triangle. International Review of Financial Analysis, 9(3), 281-297.

Jobson, J. D., \& Korkie, B. M. (1981). Performance hypothesis testing with the Sharpe and Treynor measures. Journal of Finance, 36(4), 889-908. https://doi.org/10.1111/j.1540-6261.1981.tb04891.x

Kamath, R. R., Chakornpipat, R., \& Chatrath, A. (1998). Return Distributions and The Day-of-the-Week Effects in the Stock Exchange of Thailand. Journal of Economics and Finance, 22(2-3), 97-106. https://doi.org/10.1007/BF02771480

Kim, S.-J., \& McKenzie, M. D. (2008). Autocorrelation and Stock Market Integration in the Asia-Pacific. In Asia-Pacific Financial Markets: Integration, Innovation and Challenges. Elsevier, Ltd.

Kot, H. W., \& Tam, L. H. K. (2016). Are stock price more informative after dual-listing in emerging markets? Evidence from Hong Kong-listed Chinese companies. Pacific-Basin Finance Journal, 36, 31-45. https://doi.org/10.1016/j.pacfin.2015.12.004

Lintner, J. (1965). The Valuation of Risky Assets and the Selection of Risky Investments in Stocks Portfolios and Capital Budgets. Review of Economics \& Statistics, 47(1), 13-37. https://doi.org/10.2307/1924119

Liu, Y. A., Pan, M.-S., \& Shieh, J. C. P. (1998). International Transmission of Stock Price Movements: Evidence from the U.S. and Five Asian-Pacific Markets. Journal of Economics and Finance, 22(1), 59-69. 
McKenzie, M. D., Brooks, R. D., \& Faff, R. W. (2000). The Use of Domestic and World Market Indexes in the Estimation of Time-Varying Betas. Journal of Multinational Financial Management, 10, 91-106.

Muharam, H., Mawardi, W., Arfinto, E. D., \& Najmudin, N. (2019). Volatility spillovers under difference in the degree of market integration: Evidence from the selected Asian and Eastern European stock markets. Journal of International Studies, 12(1), 134-150. https://doi.org/10.14254/2071-8330.2019/12-1/9

Najmudin, Syarif, D. H., Wahyudi, S., \& Muharam, H. (2017). Applying an international CAPM to herding behaviour model for integrated stock markets. Journal of International Studies, 10(4), 47-62. http://dx.doi.org/10.14254/2071-8330.2017/10-4/3

Ogata, H. (2012). Optimal Portfolio Estimation for Dependent Financial Returns with Generalized Empirical Likelihood. Advances in Decision Sciences, 1-8. http://dx.doi.org/10.1155/2012/973173

Oprea, O.-R., \& Stoica, O. (2018). Capital Markets Integration and Economic Growth. Montenegrin Journal of Economics, 14(3), 23-35. https://doi.org/10.14254/1800-5845/2018.14-3.2

Robiyanto, R. (2018). Indonesian Stock Market's Dynamic Integration with Asian Stock Markets and World Stock Markets. Jurnal Pengurusan, 52, 181-192. https://doi.org/10.17576/pengurusan-2018-52-15

Robiyanto, R., \& Ernayani, R. (2018). Capital market integration in some ASEAN countries revisited. Jurnal Manajemen, 22(2), 205-222. http://dx.doi.org/10.24912/jm.v22i2.359

Robiyanto, R., Santoso, M. A., \& Ernayani, R. (2019). Sharia Mutual Funds Performance in Indonesia. Business: Theory and Practice, 20, 11-18. https://doi.org/10.3846/btp.2019.02

Seiler, M. J., \& Rom, W. (1997). A Historical Analysis of Market Efficiency: Do Historical Returns Follow a Random Walk. Journal of Financial and Strategic Decisions, 10(2), 49-57.

Seth, N., \& Sharma, A. K. (2015). International Stock Market Efficiency and Integration: Evidences from Asian and US Markets. Journal of Advances in Management Research, 12(2), 88-106. https://doi.org/10.1108/JAMR-07-2011-0010

Sharma, A., \& Seth, N. (2012). Literature Review of Stock Market Integration: A Global Perspective. Qualitative Research in Financial Markets, 4(1), 84-122. https://doi.org/10.1108/17554171211213568

Sharpe, W. F. (1964). Capital Asset Prices: A Theory of Market Equilibrium Under Conditions of Risk. Journal of Finance, 19(3), 425-442. https://doi.org/10.2307/2977928

Sharpe, W. F., Gordon, J. A., \& Bailey, J. V. (1995). Investment (5th ed.). New Jersey: Prentice Hall.

Soufian, N. (2001). Empirical Content of Capital Asset Pricing Model (CAPM) and Arbitrage Pricing Theory (APT) Across Time. Manchester Metropolitan University Business School Working Paper Series, WPS010.

Thomas, N. M., Kashiramka, S., \& Yadav, S. S. (2017). Dynamic linkages among developed, emerging and frontier capital markets of Asia-Pacific region. Journal of Advances in Management Research, 14(3), 332-351. https://doi.org/10.1108/jamr-10-2016-0088

Wahyudi, S., Hersugondo, H., Laksana, R. D., \& Rudy, R. (2017). Macroeconomic Fundamental and Stock Price Index in Southeast Asia Countries: A Comparative Study. International Journal of Economics and Financial Issues, 7(2), 182-187.

Xia, Y. (2012). A Multiple-Index Model and Dimension Reduction. Journal of the American Statistical Association, 103(484), 1631-1640. https://doi.org/10.1198/016214508000000805

Yunita, Y., \& Robiyanto, R. (2018). The influence of the inflation rate, BI rate, and exchange rate changes to the financial sector stock price index return in the Indonesian stock market. Jurnal Manajemen dan Kewirausahaan, 20(2), 80-86. 